\title{
自由曲面を目標形状とする溶接ビード仕上げロボットの開発
}

\author{
谷 本 圭 司*1 則 次 俊 郎*2
}

\section{Development of a Grinding Robot for Weld Beads to Create a Free-Form Surface}

Keiji Tanimoto*1 and Toshiro Noritsugu*2

\begin{abstract}
Weld beads, which exist on the corner of an automobile doorframe, must be grinded as if there are no weld beads on it. Grinding task is usually done by skilled workers. This weld bead has joint bumps and welding distortions around the joint area. These bumps and distortions have made it difficult to develop a practicable grinding robot system. We think that grinding task should create a smooth Free-Form surface around the weld bead area, not grinding off the weld beads only. In this paper, we propose a new grinding method, which consists of four distinctive techniques. The first technique is to measure the shape of the weld bead area using a high speed CMM (Coordinate Measuring Machine). The second technique is to estimate a target Bezier surface based on the measurement data. The third technique focuses on calculating an optimum robot trajectory based on the grinding volume and the grinding belt properties. Finally, with the fourth technique, the robot will be precisely controlled to trace the calculated trajectory. This paper also presents the experimental results of grinding accuracy using this newly developed robot system.
\end{abstract}

Key Words: Bezier Surface, Weld Bead, CMM, Grinding Robot

\section{1.はじめに}

自動車のドアフレームには，コーナ部を TIG 溶接 (Tungsten Inert Gus）などにより接合しているものがある。この溶接によ り生じる溶接ビードは熟練作業者の手作業により, あたかも溶 接されていないように仕上げられている。この溶接ビード仕上 げ作業は, 典型的な $3 \mathrm{~K}$ 作業であるため, 長年ロボットによる 自動化が望まれているが, 実用的なシステムはいまだ開発され ていないのが現状である.

この溶接ビード仕上げ作業をロボットにより自動化すること が難しい要因は主に 2 点ある. 第 1 点として,この溶接は約 $0.8[\mathrm{~mm}]$ の薄い鉄板を突き合わせた状態で溶接するため, 接合 部に Fig. 1 のような接合部段差を $\pm 0.2[\mathrm{~mm}]$ 程度生じること がある．また溶接歪により溶接ビード周辺部が変形する。これ らの接合部段差と溶接歪は溶接ビードごとに異なり予測もでき ないため，ティーチング・プレイバックによるロボット制御で は，自動仕上げを実現することができない，第 2 点は，人に溶 接した痕跡を認識させないためには，溶接ビード周辺部を滑ら かな自由曲面形状に仕上げる必要があるが, 産業用ロボットに よる自由曲面加工は難しいのが現状である。 よって, 溶接ビー

原稿受付 2004 年 8 月 10 日

${ }^{* 1}$ コアテック株式会社

$* 2$ 岡山大学工学部

${ }^{* 1}$ CORETEC INC.

${ }^{* 2}$ Faculty of Engineering, Okayama University
ド仕上げ作業を自動化するには, ワークごとに異なる三次元形 状を測定・認識し，仕上げ動作をするロボットシステムが必要 になる。

仕上げ作業の自動化に関するこれまでの研究には，岩代・岡 田らが提案するレーザレンジファインダを利用したセンサベー ストロボットによるバリ仕上げ研削方法がある [1] [2].この方 法は，溶接ビードの凸部のみを除去するだけならば応用可能だ が，接合部段差がある溶接ビード周辺部に滑らかな自由曲面を 創成することはできない，また，永田らが提案する CL (Cutter

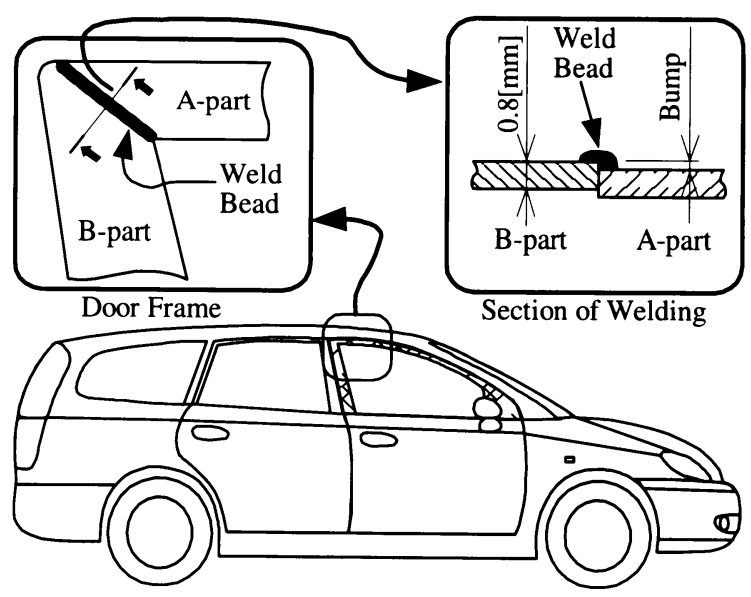

Fig. 1 Joint bump of doorframe 
Location）データに基づく力制御ロボットサンダ [3] や，井上 らが開発したマスタスレーブ方式ティーチングによる仕上げロ ボット [4] では自由曲面加工は可能だが，溶接ビードごとに異な る接合部段差・溶接歪に対応することはできない.

一方，仕上げ作業の現場においては，パウダプラズマ溶接に より, 溶接歪を少なくしたり, 溶接までの各工程を解析し, 接合 部段差を最小化する工夫などがされている。しかし，これらの 方法は，仕上げ作業を軽減することに成功しているものの，仕 上げ作業自体をなくすることはできていない，また，プレスドア のように溶接自体がないものもあるが，コスト的に有利なコー ナ部を溶接したドアフレームは, 大衆車を中心に数多く生産さ れているのが現状である，そのため，仕上げ作業は熟練作業者 に頼っており，溶接ビード自動仕上げ装置へのニーズは強い.

\section{2. 溶接ビード周辺形状測定装置の開発}

筆者らは, 溶接ビード自動仕上げ装置の開発には溶接ビード周 辺形状の解析が重要と考え, 溶接ビード周辺形状を測定する装置 として，レンジファインダと 1 軸スキャンニングユニットから構 成される Fig. 2 のような測定装置 (CMM, Coordinate Measuring Machine）を開発した [5].この装置は溶接ビード周辺部 $75 \times 75[\mathrm{~mm}]$ の範囲を $1.0 \times 0.5[\mathrm{~mm}]$ の格子状に約 5 秒で測定 することができる．測定精度は格子点あたり $\pm 50[\mu \mathrm{m}(3 \sigma)]$ であ る、この装置による自動車ドアフレーム測定結果の例を Fig. 3 に示す。この測定結果は分かりやすいように高さ方向に 10 倍 拡大し 3D 表示してある.

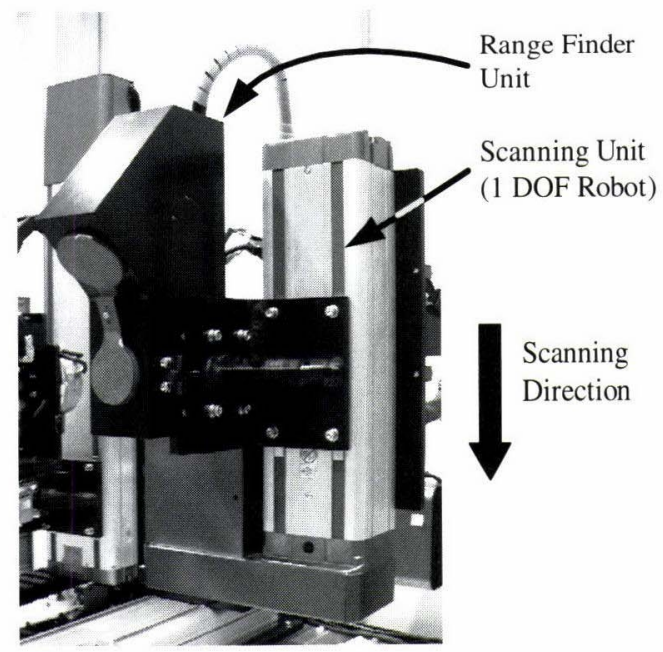

Fig. 2 CMM for weld bead

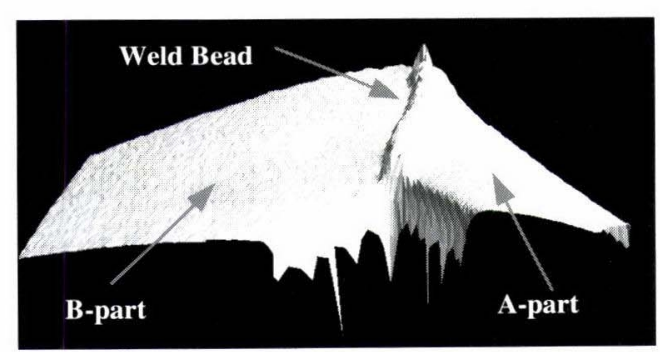

Fig. 3 Example of measurement data $(\times 10)$
この装置を利用して，接合段差を測定した結果について，接 合段差が小さい断面線の例を Fig. 4 に，接合部段差が大きい断 面線の例を Fig. 5 に示す（断面位置はFig. 1 図示部). Fig. 4 のように接合部の段差が小さい場合は, 溶接ビードを除去する だけで，滑らかな曲面を得ることが可能である（たたしこのよ うな接合部段差が小さいワークは稀にしかない). Fig. 5 のよう に接合部の段差が大きい場合は，溶接ビードを除去する以上に， 接合部段差が滑らかになるような曲面に仕上げる必要がある. このような調査・解析により，溶接ビードの仕上げとは，「溶接 ビードを除去」するのではなく，「溶接ビード周辺に滑らかな自 由曲面を作る」ということが分かり，自由曲面処理技術を利用 した溶接ビード自動仕上げ方法を提案するに至った。

\section{3. 提案する溶接ビード仕上げ方法}

\section{1 自由曲面を応用した仕上げ方法}

本論文では, ワークごとに異なる接合部段差, 溶接歪に対応 した溶接ビード仕上げ方法として，Fig. 6 に示すような方法を 提案する。この方法は, 第 1 に三次元測定機を用いて溶接ビー ド周辺形状を高速に測定する。第 2 に測定結果の点群データか ら，ベジュ工曲面を利用して仕上げ目標形状を計算する。第 3 に測定結果と仕上げ目標形状の差分から研削量を計算し, 研削 量に応じたロボット動作軌道を計算する。最後に計算されたロ ボット動作軌道をトレースするようにロボットを制御し, 溶接 ビード部を滑らかな自由曲面に仕上げる方法である。他の方法 として，ドアフレーム設計時の CAD データを利用する方法も 考えられるが, ドアフレームの現実的な製作精度や，母材厚さ が約 $0.8[\mathrm{~mm}]$ と薄いことを考慮すると, CAD 形状に合わせた のでは削り込みが深くなり, 穴空きや強度不足が生じるため, 実 用的な方法ではないと考えている。

\section{2 システムの構成}

この仕上げフローを実現するために，Fig. 7 に示すような システムを開発した。このシステムは, 三次元形状の測定から

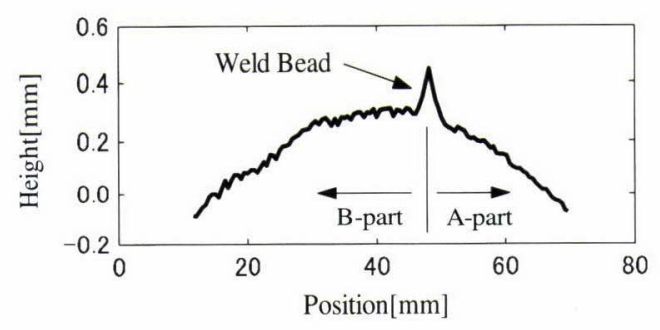

Fig. 4 Example of small joint bump

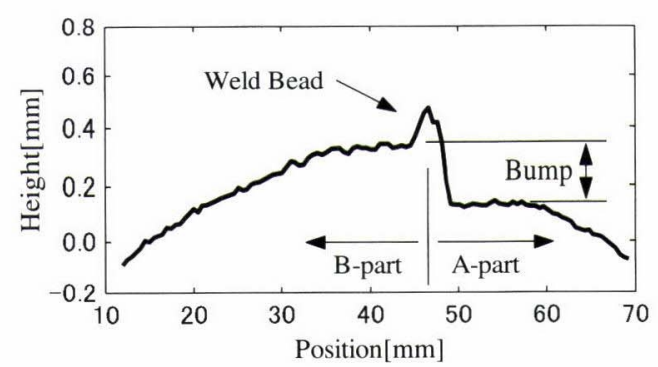

Fig. 5 Example of large joint bump 


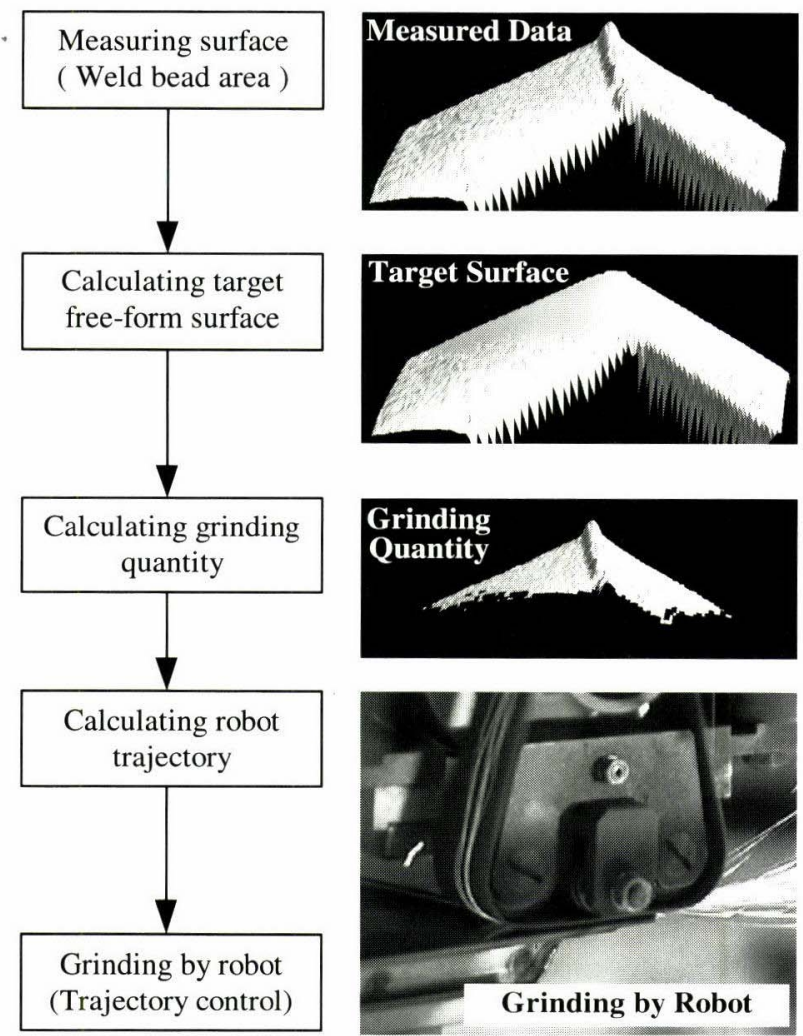

Fig. 6 Flowchart of proposed grinding

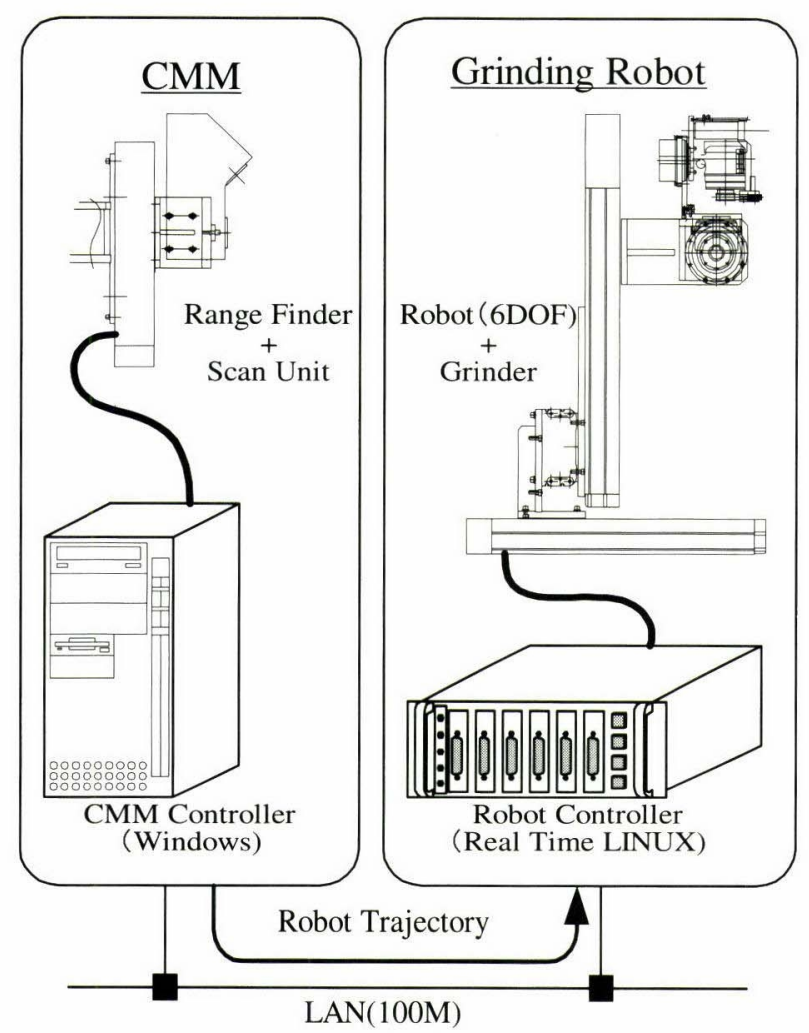

Fig. 7 Structure of proposed system
ロボット動作軌道計算までをする測定機コントローラ（CMM Controller）と, 計算された動作軌道に基づきロボットを制御 するロボットコントローラから構成されている．測定機コント ローラは，レンジファインダとスキャンニングユニットを制御 し溶接ビード周辺の三次元形状を測定するとともに, 仕上げ目 標形状の計算, 研削目標体積の計算, ロボット動作軌道の計算 を行っている．計算されたロボット動作軌道データは約 1 [MB] と大きいため, 制御盤内の 100 M-LAN を経由してロボットコ ントローラへ送られる。ロボットコントローラは送られた軌道 デー夕を忠実にトレースするように軌道追従制御をしている。 ロボットは溶接ビード仕上げ用に開発されたものであり, 直交 3 自由度, 回転 3 自由度, 溶接ビード仕上げ用グラインダなど から構成されている。

\section{4. 仕上げ目標形状計算}

\section{1 仕上げ目標形状の数値表現}

この溶接ビード仕上げ方法では，まず仕上げ目標形状を三次 元空間内の曲面として数值表現する必要がある。そこで熟練作 業者が仕上げた曲面を測定し，ベジュエ曲面の近似曲面を計算 したところ， $\pm 50[\mathrm{~mm}]$ の精度で近似することができたため，仕 上げ目標形状の数值表現方法にベジュエ曲面を選定した。次に この仕上げ目標形状計算は，次の 3 要件を満たす必要がある。 第 1 に研削部と非研削部の境界領域を滑らかに接続すること. 第 2 に削り込み量が規定值以上にならないこと（約 $0.3[\mathrm{~mm}]$ 以上削り込むと強度低下, 穴空きの原因になる). 第 3 に測定 点より下側に仕上げ目標形状を作ることである。これらの要件 を満たした滑らかな自由曲面を表現するため, 双 3 次または双 4 次ベジュエ曲面を利用した仕上げ目標形状の計算方法につい て研究を進めた。双 3 次ベジュエ曲面は, Fig. 8 のように, 16 点の制御点で定義され, 曲面上の点は媒介変数 $s, t$ 老利用して 式（1）のように表される.なお式（1）で使われている $B_{i}^{n}$ は Bernstein 多項式で式（2）のようになる.

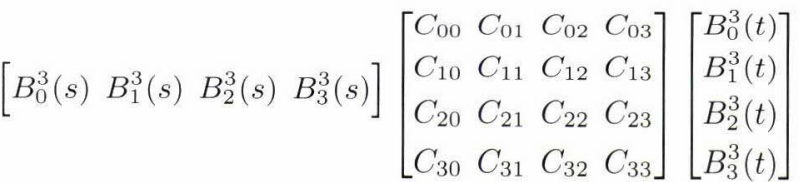

$$
\begin{aligned}
& B_{i}^{n}(t)=\frac{n !}{(n-1) ! i !} t^{i}(1-t)^{n-1}
\end{aligned}
$$

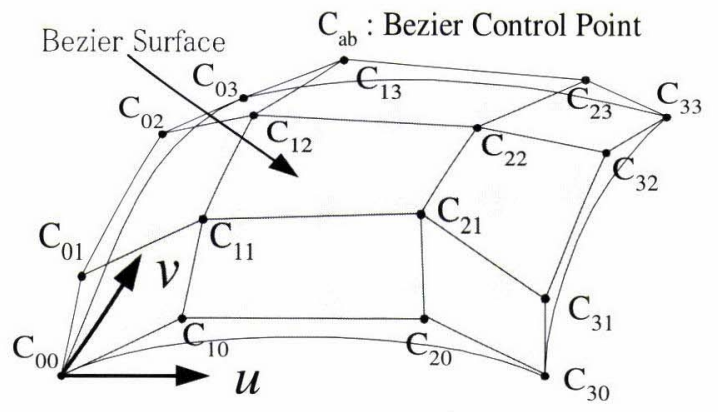

Fig. 8 Control points of Bezier surface 


\section{2 仕上げ目標形状の計算方法}

開発した仕上げ目標形状の計算フローを Fig. 9 に示す。測 定結果である溶接ビード周辺形状デー夕は $0.5 \sim 2.0[\mathrm{~mm}]$ の格 子状データになっており，Fig.10のようにワーク表面側が Z 軸十方向になるように座標変換している，仕上げ目標形状の計 算はまずこの測定結果点群データから目標形状計算に不要とな る溶接ビード部, ワーク端面部のデー夕を捨てる (trimming). 次に残された有効測定点およそ 7,000 点から最小二乗法を利用 し近似べジュエ曲面を計算する。

測定結果から双 3 次の近似べジュ工曲面を計算するには，求 めるべジュエ曲面パッチの範囲を決めるコーナ部の 4 制御点 $\left(C_{00}, C_{03}, C_{30}, C_{33}\right)$ の $x, y$ 座標值を定義し, $z$ 座標値は 最小二乗法で求める. 残りの 12 制御点については, 式 (3) の 双 1 次線織面（ruled surface [6]）を用い等分割（媒介変数 $s, t$ を $0 ， \frac{1}{3} ， \frac{2}{3} ， 1$ に設定）した值とする.このように制御点の $x$, $y$ 座標値を等分割に設定することにより, 近似べジュエ曲面の 計算に必要となる媒介変数 $s, t$ の值を測定結果の $x, y$ 座標值 から容易に求めることが可能になる. 双 1 次線織面を利用する と, 媒介変数は 2 次式の解となるため高速に計算することがで きる. ベジュエ曲面制御点の $x, y$ 座標值を, Fig. 10 のように

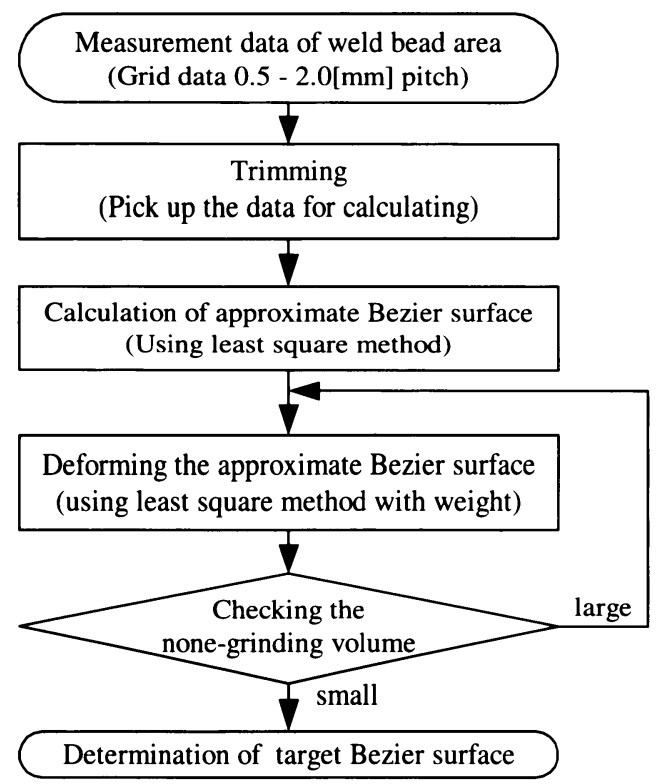

Fig. 9 Flowchart of calculating target Bezier surface

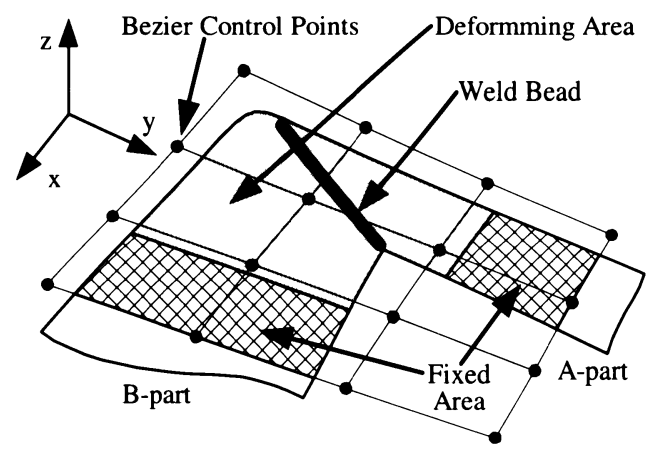

Fig. 10 Deforming area ans fixed area
事前に決めておき， $z$ の值を最小二乗法で求め近似べジュエ曲 面を求めることになる。この計算を約 7,000 点の有効測定点に 対して行うことにより，測定結果が真值に対し正規分布する場 合, 測定数の平方根に応じた精度向上が期待できるため, 測定 精度 $\pm 50[\mu \mathrm{m}(3 \sigma)]$ の CMM でも， $\pm 5[\mu \mathrm{m}]$ 以上の精度で近似 ベジュエ曲面を求めることが可能となる。

$$
\left[\begin{array}{l}
x \\
y \\
z
\end{array}\right]=\left[\begin{array}{ll}
1-s & s
\end{array}\right]\left[\begin{array}{ll}
C_{00} & C_{03} \\
C_{30} & C_{33}
\end{array}\right]\left[\begin{array}{c}
1-t \\
t
\end{array}\right]
$$

次に, 求めた近似べジュエ曲面から，仕上げ目標形状に変形さ せる計算を行う。この変形計算は, 式 (4) のように最小二乗和 (SSE, Sum of Squared Errors）の重み付けを調整することで 行う.この式で $\hat{Z}_{i}$ は目標形状のベジュエ曲面, $Z_{i}$ は測定結果の $\mathrm{Z}$ 軸座標值, $w_{i}$ は重みを示している。この式に式（1）のベジュ 工曲面の式を代入し最小二乗値となる $\mathrm{Z}$ 軸の值を求めている. 双 3 次ベジュエ曲面の場合, 制御点は 16 点となり, 求める制御点の $Z$ 軸座標値は, 式 (5) のように整理され, $16 \times 16$ の行列計算を すれば求めることができる. 式（5）の $\left[C_{00 z}, C_{01 z}, \ldots, C_{33 z}\right]$ が求める $z$ 軸座標値である. $L_{a b c d}$ は, 測定結果の $x, y$ から求 めた $s, t$ から計算され, $M_{a b}$ は $s, t$ と测定結果の $z$ 座標值か ら計算される.

$$
S S E=\sum_{i=1}^{n} w_{i}\left(\hat{Z}_{i}-Z_{i}\right)^{2}
$$

$$
\left[\begin{array}{c}
C_{00 z} \\
C_{01 z} \\
\vdots \\
C_{33 z}
\end{array}\right]=\left[\begin{array}{cccc}
L_{0000} & L_{0001} & \ldots & L_{0033} \\
L_{0100} & L_{0101} & \ldots & L_{0133} \\
\vdots & \vdots & \ddots & \vdots \\
L_{3300} & L_{3301} & \ldots & L_{3333}
\end{array}\right]^{-1}\left[\begin{array}{c}
M_{00} \\
M_{01} \\
\vdots \\
M_{33}
\end{array}\right]
$$

$$
\begin{gathered}
L_{a b c d}=\sum_{i=1}^{n} w_{i}\left(B_{a}^{3}\left(s_{i}\right) B_{b}^{3}\left(t_{i}\right) B_{c}^{3}\left(s_{i}\right) B_{d}^{3}\left(t_{i}\right)\right) \\
M_{a b}=\sum_{i=1}^{n} w_{i}\left(B_{a}^{3}\left(s_{i}\right) B_{b}^{3}\left(t_{i}\right) Z_{i}\right)
\end{gathered}
$$

二乗和の重み $w_{i}$ は, 測定デー夕を Fig. 10 のように変形を最 小限にする固定領域（Fixed area）と変形させる変形領域（Deformming area）に分けて設定している. 固定領域は, 研削部と 非研削部の境界領域で, 最小二乗和の重み付けを 1.0 に固定し, 滑らかな曲面の接続を実現している。変動領域は，基準となる 近似べジュエ曲面に対して，下側にある測定点の重み付けを重 く，上側にある測定点の重み付けを軽くすることにより，曲面 を下げる変形処理を実現している。 その後, 変形したべジュ工 曲面に対し研削できない部分（測定結果が変形後べジュエ曲面 より下にある部分）の総体積を求める。この研削できない部分 の総体積が規定值を上回った場合は再度変形処理を行う.下回っ た場合, 研削可能と判断し, 仕上げ目標形状としている.この 計算の過程で削り込み深さが規定值（約 $0.3[\mathrm{~mm}]$ ）以上になっ た場合は，ワークの強度低下，穴空きの原因になるため，NG ワークとして装置外に出すように使用者に促すようにしている. 
このような計算により，研削開始部と非研削部を滑らかに接続 するとともに, 研削可能な溶接ビード仕上げ目標形状を求めて いる.

\section{5.ロボットの動作軌道生成と制御}

\section{1 研削目標体積の計算}

溶接ビード仕上げ目標形状が決まると，測定結果と目標形状 との差分から研削目標体積を求めることができる．5 本のワー クに対して研削目標体積とワーク内側の接合部段差を計算した 例を Table 1 に示す。研削目標体積は，接合部段差などによ り，2 倍以上異なることが分かる.

溶接ビード周辺部を目標形状に仕上げるには，計算された研 削目標体積を研削するロボットの動きを実現すればよい。この ロボットの動きは, 砈石ベルトの単位時間当たり研削量を定量 的に把握し, 目標とする研削体積に応じてグラインダ送り速度 を加減速するものとなる，つまり，研削体積が多い部分はゆっ くりとグラインダを送り, 研削体積が少ない部分は早くグライ ンダを送る。このようなロボットの動きを作るには, 砥石の単 位時間研削量の定量化が重要となる。なお, 砥石は磨耗や变形 の少ないベルトタイプ（砥石ベルト）を利用した。

\section{2 砥石ベルト単位時間研削量の定量化}

砥石ベルトの単位時間研削量は, 砥石押し付け力, 砥石周速 度, 砥粒材質（酸化アルミ，ジルコニアなど）, 粒度に加え, 砥 石の製法，寿命などの各種要因によっても異なる。しかし，利 用する砥石べルトを決めれば，砥石押し付け力と砥石周速度を 管理することにより, 単位時間研削量を把握することが可能に なる。そこで, Fig.11のような装置を準備し, 単位時間研削 量について調べた。このグラインダの砥石押し付け力は，エア フローティング機構により任意の值に設定可能である（砥石押 し付け力を力制御する研究 [3] [7] もあるが, このグラインダで はエアフローティング機構で代用している）。また, 砥石ベル トの周速度は, 高周波モータにより任意周速度が設定可能であ る. 試験片には断面 $8.0 \times 8.0[\mathrm{~mm}]$ の鉄棒を使っている. 単位 時間研削量は, 研削中に試験片の高さ変化を変位センサで測定 することにより求めている．Fig. 12 は試験片を研削している 時の変位センサの出力である。この測定では, 砥石が試験片に 接触してから 1.0 - 2.5 秒のデー夕を収集し, 時間に対する変位 の傾きを最小二乗法で求めることにより，単位時間研削量を求 めている. 1.5 秒間で $0.2[\mathrm{~mm}]$ の変位があることから, 単位時 間研削量が $8.5\left[\mathrm{~mm}^{3} / \mathrm{s}\right]$ であることが分かる。この砥石べルト の単位時間研削量を測定する機能は, 砥石ベルトの自動校正工 ニットとして装置に組込まれており，10２0本のワークを研削 するごとに, 砥石の単位時間研削量の校正を行っている.

Table 1 Sample of grinding volume and bump

\begin{tabular}{|r|r|r|}
\hline Work no. & Volume $\left[\mathrm{mm}^{3}\right]$ & Bump $[\mathrm{mm}]$ \\
\hline 1 & 108 & 0.02 \\
\hline 2 & 131 & 0.03 \\
\hline 3 & 164 & 0.09 \\
\hline 4 & 229 & 0.12 \\
\hline 5 & 252 & 0.15 \\
\hline
\end{tabular}

Fig. 13 は砥粒材質ジルコニア, 粒度＃60 の砥石ベルトを利 用し, 砥石周速度が $14.5[\mathrm{~m} / \mathrm{s}]$ のときの, 砥石押し付け力と単 位時間研削量の関係を調べた結果で，Fig. 14 は，同じ砥石べ ルトで押し付け力が $20[\mathrm{~N}]$ 時の, 砥石周速度と単位時間研削量 の関係を調べた例である。このように, 砥石の単位時間研削量 は, 砥石押し付け力, 砥石周速度にほほ比例の関係にあること が確認できる。

砥石寿命を測定した結果を Fig. 15 に示す。この測定は, 砥粒ジルコニア, 粒度\#100, 砥石押し付け力 $16[\mathrm{~N}]$, 周速度 $14.5[\mathrm{~m} / \mathrm{s}]$ の条件下で, 試験片を繰り返し研削し, 総研削体積に 対する単位時間研削量の変化を求めたものである。この図から 単位時間研削量が徐々に減少し, 総研削体積が約 $6,000\left[\mathrm{~mm}^{3} / \mathrm{s}\right]$ 弱のところで単位時間研削量がほほ $0\left[\mathrm{~mm}^{3} / \mathrm{s}\right]$ となり寿命に達 していることが分かる。研削開始から寿命に達するまでの間は, 単位時間研削量の変化が小さいため, 定期的に単位時間研削量 を測定することにより，ロボット動作軌道に必要となる単位時 間研削量を求めることが可能である. 以上のように, 砥石ベル トの単位時間研削量を定量化し，ロボット動作軌道計算に利用 している.

\section{3 ロボット動作軌道生成}

溶接ビード仕上げのロボット動作軌道を生成するためには, グ ラインダの位置と送り速度を正確に定義することが重要になる。

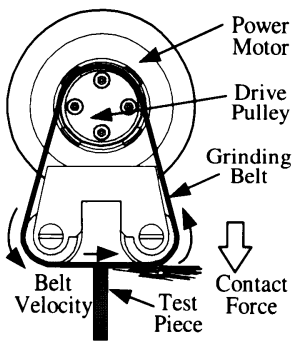

Fig. 11 Testing equipment

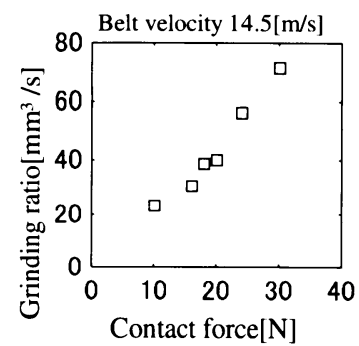

Fig. 13 Contact force

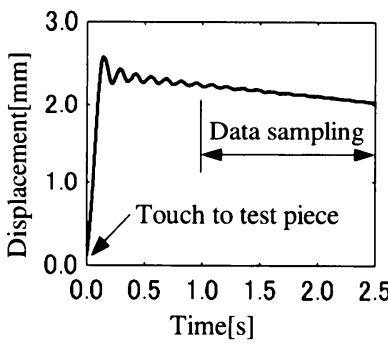

Fig. 12 Grinding test piece

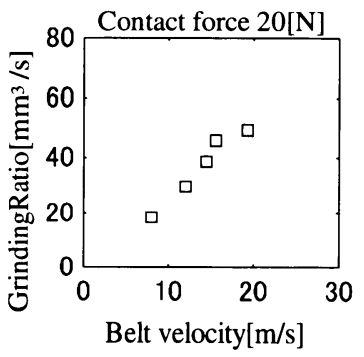

Fig. 14 Belt velocity

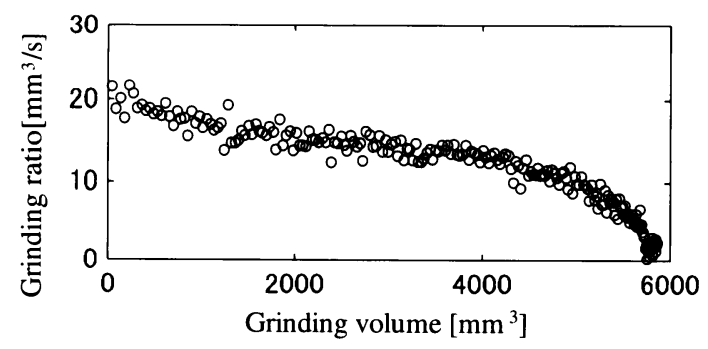

Fig. 15 Life time of grinding belt 


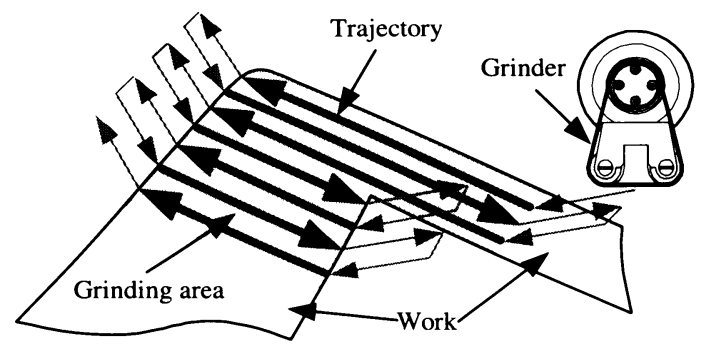

Fig. 16 Template of robot trajectory

そこでFig. 16 のような研削パターンを仕上げ目標形状に投影 することにより，三次元空間上の自由曲線データとして経路を 求めている. 次に経路上の研削目標体積と砥石の単位時間研削 量からグラインダ送り速度を設定し， ロボットの動作軌道を求 めている.ただしこの段階でロボットとして動作可能なように， 最大加減速度, 最大最小速度を制限している。ロボットの動作 軌道が決まった後，一定時間間隔 $(3 \sim 10[\mathrm{~ms}])$ のグラインダ 位置と姿势を求め, ロボットの各軸位置デー夕に幾何学的な解 法で逆運動学变換している.なお, 逆運動学变換時の特異点対 策は，仕上げ動作中の姿勢変化が少ないこともあり，機械的に 特異点処理が不要となる軸構成にしている。

また, 目標位置を計算する時間間隔は, 位置サーボ周期であ る $1[\mathrm{~ms}]$ が理想だが, 多くの計算時間と通信時間を必要とする. そのため, 計算時間間隔を $3 \sim 10[\mathrm{~ms}]$ に間引き， ロボットの動 作軌道計算時間 2 秒以下, 通信時間 0.5 秒以下を実現している. 時間的に間引かれた目標位置データは，ロボットコントローラ 側で, 3 次の多項式を利用し, 位置サーボ周期ごとの目標位置 に補間されている.

このように, CAM でいう CL 的な点群デー夕に時間的な意味 を付与し，位置と送り速度を正確に設定すると同時にポストプ ロセスまで行うことによりロボットの動作を定義している，筆 者らは, この位置と送り速度情報をもった点群デー夕を Time Base CL と呼んでいる。 今回開発した溶接ビード仕上げ用口 ボットコントローラには, この Time Base CL データをLAN 経由で受信し, 軌道追従制御できる機能が開発されている.

\section{4 軌道追従ロボット制御}

この溶接ビード仕上げ用ロボットは並進 3 軸 $(\mathrm{XYZ})$ ，回転 3 軸（ABC）から構成されており，各軸ごとにFig.17のような 位置制御を行っている。このコントローラは位置サーボをべー スに, 速度フィードフォワード制御を入れ, 軌道追従性を向上 させている. 並進軸の制御パラメータを Table 2, 回転軸の制 御パラメータを Table 3 に示す。これらのパラメータのうち,

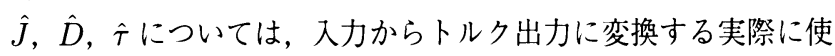

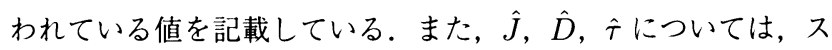
テップ応答, 一定速度駆動時のトルク值から求めた. $\mathrm{Kp}, \mathrm{Kv}$ については，実験的にロボットの動作が振動的にならない值に 設定した．結果的に $\mathrm{Kp}, \mathrm{Kv}$ は全軸共通の値となっている.

このコントローラは, 特殊用途 [8] [9] ロボットのコントロー ラとして筆者らが継続的に開発しているもので, 現在はリアル タイム制御が可能な LINUX 上に構築されている. 今回開発し た Time Base CL データによる軌道追従性について, Fig. 18
則 次 俊 郎

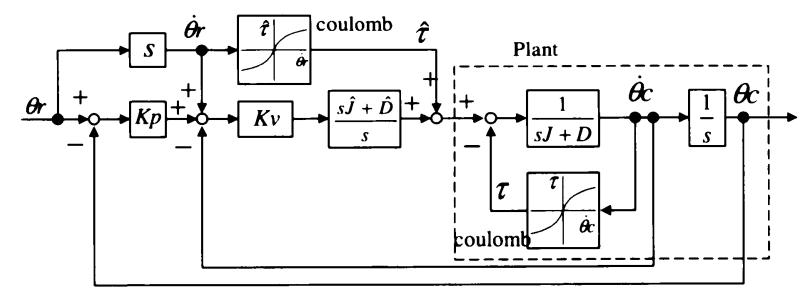

Fig. 17 Controller of robot

Table 2 Parameters of linear motion actuator

\begin{tabular}{|c|c|c|c|c|c|}
\hline Axis & $\mathrm{Kp}[1 / \mathrm{s}]$ & $\mathrm{Kv}[1 / \mathrm{s}]$ & $\hat{J}\left[\mathrm{Ns}^{2}\right]$ & $\hat{D}[\mathrm{Ns}]$ & $\hat{\tau}[\mathrm{Nm}]$ \\
\hline $\mathrm{X}$ & 100 & 50 & 0.255 & 2.13 & 0.0509 \\
\hline $\mathrm{Y}$ & 100 & 50 & 0.427 & 1.37 & 0.0771 \\
\hline $\mathrm{Z}$ & 100 & 50 & 0.214 & 1.78 & 0.134 \\
\hline
\end{tabular}

Table 3 Parameters of rotary motion actuator

\begin{tabular}{|c|c|c|c|c|c|}
\hline Axis & $\mathrm{Kp}[1 / \mathrm{s}]$ & $\mathrm{Kv}[1 / \mathrm{s}]$ & $\hat{J}\left[\mathrm{Nms}^{2} / \mathrm{deg}\right]$ & $\hat{D}[\mathrm{Nms} / \mathrm{deg}]$ & $\hat{\tau}[\mathrm{Nm}]$ \\
\hline A & 100 & 50 & 0.433 & 2.35 & 4.91 \\
\hline B & 100 & 50 & 0.0898 & 0.460 & 4.17 \\
\hline C & 100 & 50 & 0.0654 & 0.417 & 5.40 \\
\hline
\end{tabular}

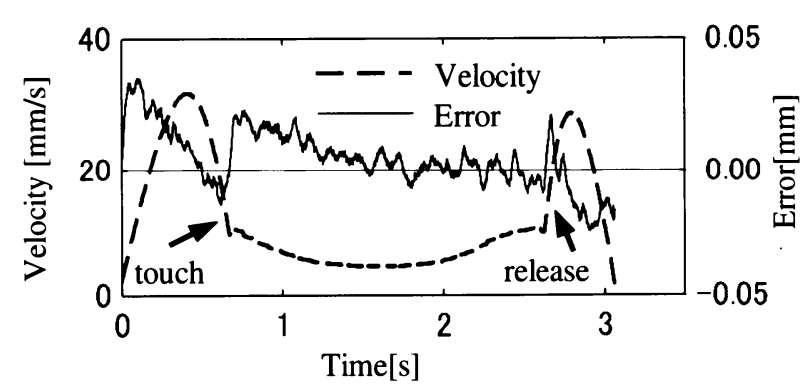

Fig. 18 Target velocity and position error

に, 待機・研削 ·退避の一連動作の動作目標速度と位置制御工 ラーを示す。このグラフでは， $0.0 〜 0.7$ 秒までが待機位置から ワークに接触する動作で，0.7〜2.6 秒までが研削動作である. この研削動作の目標速度は, 研削体積に応じてて変化させている. 研削動作中の位置制御エラーは $\pm 25[\mu \mathrm{m}]$ に入っており, 軌道 追従性が確保されていることが確認できる。位置制御エラーが $\pm 200[\mu \mathrm{m}]$ を超えると仕上げ面に喰い込み傷が発生し品質不良 になる.

\section{6. 溶接ビード仕上げ実験}

本研究では, 提案する溶接ビード仕上げ方法を検証するため, Fig. 19 のような装置を開発した。この装置は, 溶接ビード仕上 げ用に開発したグラインダと並進 3 軸, 回転 3 軸の 6 自由度ロ ボットから構成されるロボットユニットと, レンジファインダと 単軸スキャンニングユニットから構成される計測ユニットから 構成されている。並進アクチュエータはXYZの 3 軸共通で定格 出力 $400[\mathrm{~W}]$ のサーボモータと, リード $10[\mathrm{~mm}]$ のボールネジ を利用し構成している. 回転軸は A 軸に最大トルク $260[\mathrm{Nm}]$, $\mathrm{BC}$ 軸に最大トルク $64[\mathrm{Nm}]$ の回転アクチュエータを利用して いる.

この開発した装置を利用して, 溶接ビード仕上げ実験を行っ 


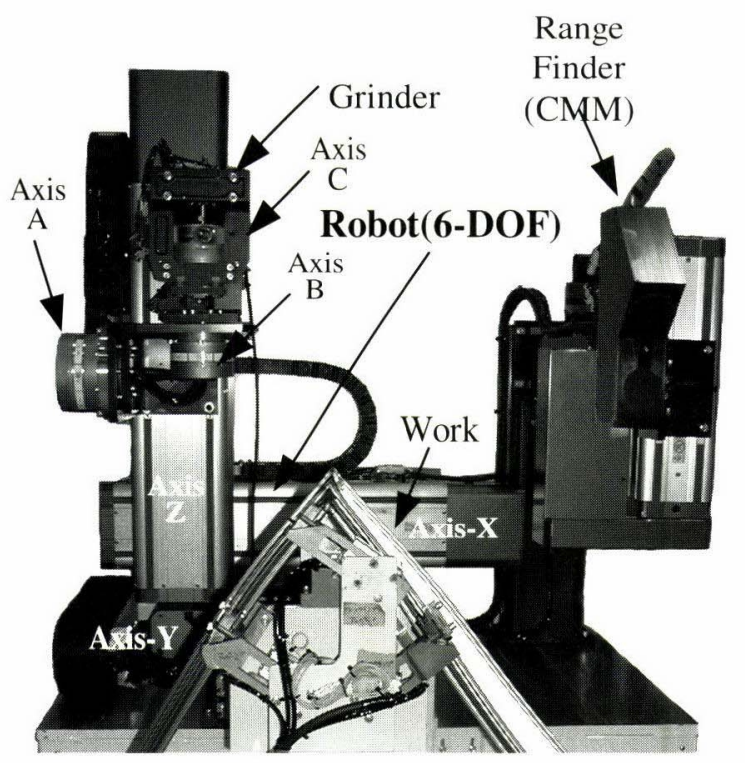

Fig. 19 Developed weld bead grinding system

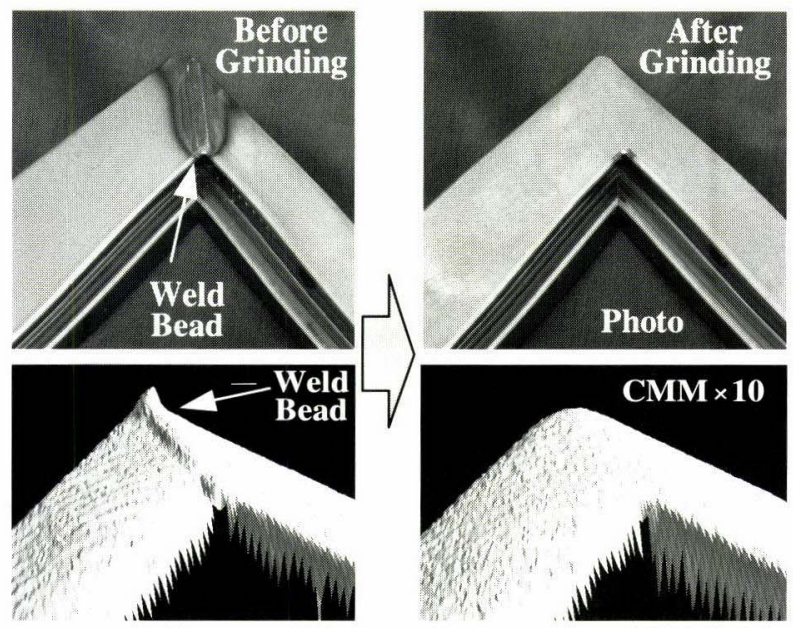

Fig. 20 Experimental results of grinding

た．仕上げ前と後の測定結果を Fig. 20 に示す。このワークに は，接合部段差が約 $0.1[\mathrm{~mm}]$, 溶接ビードが約 $0.2[\mathrm{~mm}]$ （いず 妃も最大值）あったが, 図の仕上げ後ワークのように熟練作業 者に近い仕上げ品質を得ることができた。

また，測定結果から計算された仕上げ目標形状と，仕上げ後 ワーク測定結果の差分を Fig. 21 に示す。このように仕上げ目 標形状に対して $0.04 \sim 0.06[\mathrm{~mm}]$ の精度で研削できていること が確認できる。他のワークに対しても同様の評価を行ったとこ ろ, $\pm 0.1[\mathrm{~mm}]$ 以内の精度で研削できていることが確認できた。 この仕上げ目標形状と測定結果に䛊差が生じた原因について調 ベたところ, グラインダ動作速度が速度上限に達し, 研削体積 から得られるグラインダ送り速度より遅くなったため, 過剩研 削が発生していることが分かった。このことから，ロボットの 運動性能を向上 (高い加減速) させることにより, さらに研削 精度を向上できるものと考えている。

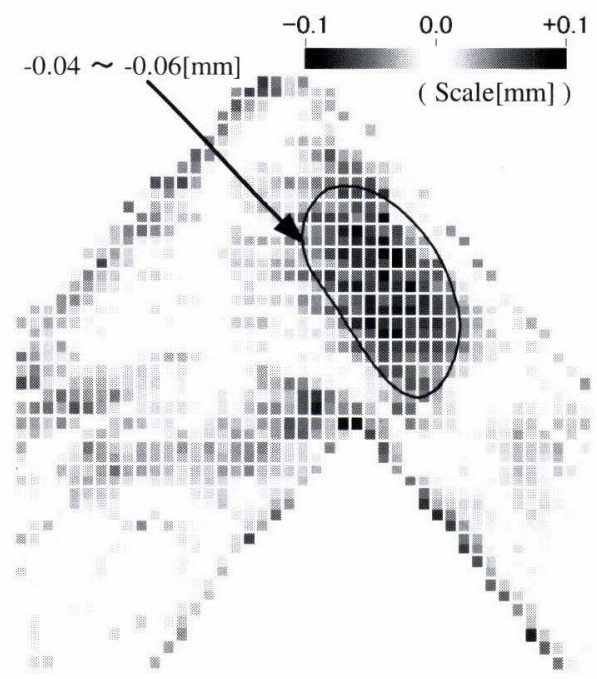

Fig. 21 Differrence color map

7.おわりに

本論文では，測定結果から仕上げ目標形状を計算し，研削目 標体積に応じたロボット動作軌道を制御することにより，熟練 作業者レベルの仕上げ品質を達成可能なことを示した。この溶 接ビード仕上げ装置は, ワークのセット・三次元形状測定・ロ ボットによる仕上げ・ワークの取り出しまでの一連動作を 30 50 秒内で行っている。熟練作業者も同等の時間で一連の作業を 行っているため，十分実用的なシステムになっていると考えて いる。仕上げ品質についても，この仕上げ装置を用いた数十本 単位の自動仕上げ実験を行い, 熟練作業者から品質が十分であ ると確認された。ただし，このような熟練者による評価は感覚 的なものであるため, 今後は人が自然に感じられる滑らかな曲 面とはどのような曲面なのか, 定量的に扱えるように研究を進 めて行きたい。また，この三次元形状測定，自由曲面処理，口 ボット制御技術を，金型磨きなどの仕上げ作業や，三次元空間 に㧍けるレジストレーションが課題となる医療用ロボット [10] などへも応用して行きたい。

謝 辞 本研究は, 課題対応新技術研究開発事業の一環とし $\tau$, 中小企業総合事業団（現：独立行政法人中小企業基盤整備 機構）から委託を受け実施しました。また，研究開発を進める に当たり，仕上げ品質に関する貴重なアドバイスや評価をシロ キ工業株式会社の諸氏から頂きました。ここに謝意を表します。

\section{参 考 文 献}

[1] 岩城, 松尾, 岡田, 水川：“センサベーストロボットによるバリ仕上 げ研削”, 日本ロボット学会誌, vol.15, no.6, pp.893-900, 1997.

[2] 岡田, 岩城, 水川, 松尾, 金山, 奥平: “高精度バリ研削のためのバリ 付近形状計測方式とその評価”, 日本ロボット学会誌, vol.15, no.6, pp.901-910, 1997.

[3] 永田, 渡邊, 津田, 川口, 藤本, 村瀬： “多軸制御用 CL デー夕に基 づく倣い制御器を用いた力制御ロボットサンダーの開発とその評価実 験”, 日本精密工学会誌, vol.68, no.7, pp.953-957, 2002.

[4] 井上昭史：“仕上げロボット”, 日本ロボット学会誌, vol.13, no.6, pp. $752-755,1995$

[5] 谷本, 則次: “3 次元形状認識による溶接ビード自動仕上げシステムの 開発 溶接ビード 3 次元形状測定装置の開発”, 第 19 回日本ロボッ 
卜学会学術講演会講演論文集, pp.123-124, 2001.

[6] G. Frain:CAGD のための曲線・曲面理論. p.180, 共立出版, 1991.

[ 7] 神野, 栗田：“機械加工バリ取り作業を対象とした力制御の追従性向 上”, 日本ロボット学会誌, vol.17, no.1, pp.147-155, 1999.

[8] 則次, 谷本, 安原, 馬島：“ニューラルネットワークを用いた大型液晶 基板搬送ロボットの学習制御”, 日本機械学会論文集, vol.67, no.664, C 編, 2001.
[9] 谷本, 光石, 割澤, 蔵本, 鈴木, 田島: “人工膝関節置換術支援ロボッ トの開発”, 日本機械学会松山地方講演会論文集, 2002.

[10] M. Mitsuishi, S. Warisawa, F. Tajima, M. Suzuki, K. Tanimoto and K. Kuramoto: "Development of a 9 Axes Machine Tool for Bone Cutting," CIRP ANNALS 2003 Manufacturing Technology, p.327, 2003.

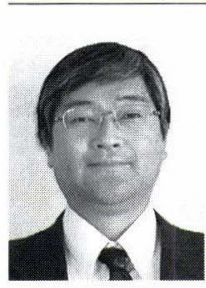

谷本圭司（Keiji Tanimoto）

1965 年 1 月 11 日生. 1988 年早稲田大学理工学 部卒業. 同年トヨ夕自動車株式会社入社. 1994 年 コアテック株式会社入社. 溶接ビード自動仕上げロ ボット，人工膝関節手術支援ロボットの研究開発に 従事.

(日本ロボット学会正会員)

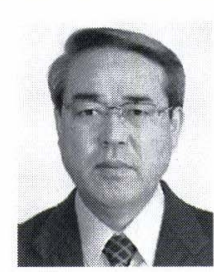

則次俊郎 (Toshiro Noritsugu)

1949 年 10 月 19 日生. 1974 年岡山大学大学院工 学研究科修士課程修了. 津山工業高等専門学校を経 て, 1986 年岡山大学工学部助教授, 1991 年同機械 工学科教授, 1996 年同システム工学科教授, 現在 に至る. 1982 年工学博士 (京都大学). 空気圧アク チュエータ, ウェアラブルロボット, 機械システム の高機能化制御に関する研究に従事。(日本ロボット学会正会員) 